\title{
GÊNEROS DISCURSIVOS EM ATIVIDADES DE INICIAÇÃO CIENTÍFICA COM ALUNOS DA EDUCAÇÃO BÁSICA
}

\author{
DISCURSIVE GENRES AT ACTIVITIES OF SCIENTIFIC \\ INITIATION WITH ELEMENTARY SCHOOL STUDENTS
}

\author{
Wagner Rodrigues Silva ${ }^{1}$ \\ Elizangela da Rocha Fernandes ${ }^{2}$ \\ Monique Wermuth Figueras ${ }^{3}$
}

\begin{abstract}
Resumo: Investigamos como os gêneros discursivos organizam as atividades de iniciaçâo científica numa escola pública de ensino básico e contribuem para o fortalecimento do letramento científico dos alunos na instituiçáo. Assumimos uma abordagem qualitativa de pesquisa, realizada a partir do cruzamento de diferentes fontes de pesquisas produzidas espontaneamente no contexto escolar e especificamente para este estudo. O trabalho pedagógico com gêneros do domínio científico produziu situaçôes de ensino diferenciadas, mas bastante marcadas por práticas indesejadas da cultura escolar. Os resultados mostraram ainda a necessidade de readequar as condiçôes de trabalho do professor e de investir na formaçăo desse profissional como pesquisador e produtor de conhecimentos.
\end{abstract}

Palavras-chave: Feira científica escolar. Letramento científico. Linguagem.

Abstract: We investigate how discursive genres organize activities of scientific initiation at a public elementary school and contribute to the empowerment of students'scientific literacy at the institution. We assume a qualitative research approach carried out from the intersection of different research sources spontaneously produced in the school context and specifically for this study. The pedagogical work with genres from the scientific domain has produced differentiated situations of teaching however still quite marked by undesirable school culture practices. The results also pointed out the need to rearrange teacher's work conditions and to invest in the development of this practitioner as a researcher and a knowledge producer.

Keywords: Language. School scientific exhibition. Scientific literacy.

1 Doutor em Linguística Aplicada - Docente da Universidade Federal do Tocantins (UFT) e Bolsista Produtividade do CNPq.wagnerodriguesilva@gmail.com

2 Mestra em Letras: Ensino de Língua e Literatura pela Universidade Federal do Tocantins (UFT). E-mail: elizan_gbi@hotmail.com

3 Professora efetiva da Secretaria de Educaçâo do Estado do Tocantins e da Secretaria Municipal de Educaçăo de Palmas.mwfigueras@gmail.com 


\section{INTRODUÇÃO}

Para ressaltar a importância da familiarizaçăo dos alunos com atividades científicas no cotidiano escolar, diversas instituiçôes brasileiras de ensino básico elaboram atividades identificadas como Feira de Ciência, Feira de Conhecimento ou Mostra Científica, só para citarmos algumas denominaçōes correntes para esses eventos anuais, muitos com datas já definidas nos calendários escolares, quando os alunos compartilham, com a comunidade interna e externa à instituiçăo, parte do conhecimento construído com os professores nas interaçóes diárias (cf. Bertoldo; Cunha, 2016)4.

Neste artigo, analisamos como alguns gêneros discursivos organizam as atividades de iniciaçăo científica e de divulgaçăo do conhecimento dos educandos, numa escola pública municipal na capital da mais jovem unidade federativa brasileira, na cidade de Palmas, Estado do Tocantins. Para tanto, procuramos compreender como algumas atividades de escrita, em torno de feiras científicas escolares, podem contribuir especialmente para o letramento científico dos atores sociais envolvidos.

O corpus desta pesquisa é composto por textos de diferentes gêneros produzidos pelos alunos, a exemplo de diários de bordo, projetos de pesquisa, pôsteres científicos, além de cenas fotografadas dos alunos em atividade e de entrevistas realizadas com alguns professores da instituiçấo de ensino focalizada. Com exceçâo das entrevistas, os documentos investigados encontravam-se arquivados e foram cedidos pela própria escola municipal e pela secretaria municipal de educaçăo. No tocante às atividades de familiarizaçăo dos alunos com práticas de pesquisa, náo acompanhamos o processo pedagógico, tivemos acesso aos documentos integrantes do corpus como produtos arquivados nas referidas instituiçōes.

Diferentemente do diagnóstico realizado por Bertoldo e Cunha (2016), em escolas de Ensino Médio no município de Toledo (PR), ao identificarem apenas três escolas que realizam Feiras Científicas, entre quatorze instituiçōes pesquisadas, o município de Palmas criou o projeto Educaçăo Científica no Cotidiano Escolar. A partir da PORTARIA/GAB/SEMED/Nº361, publicada no dia 20 de março de 2014, no Diário Oficial de Palmas, instituiu-se a Feira de Ciências, Inovaçăo e Tecnologia de Palmas (FECIT), "com a finalidade de investir na formaçâo científica de educadores do Ensino Fundamental e EJA" (PALMAS, 2014, p. 12), além de "mobilizar a populaçăo, em especial crianças, adolescentes e jovens, [...] identificando talentos, valorizando a criatividade na elaboraçấo e execuçâo dos projetos e propiciando o debate sobre as estratégias e mudanças necessárias para a popularizaçăo da Ciência" (Palmas, 2014a, p. 4).

A partir do referido marco, no mês de junho, săo realizadas as feiras científicas escolares, nas quais os trabalhos dos alunos săo avaliados e selecionados para serem apresentados na FECIT. Cada escola envia um trabalho por modalidade de ensino que será apresentado como finalista na feira municipal (FECIT). No referido evento, por sua vez, um trabalho da rede municipal é selecionado para representar a FECIT na Feira Brasileira de Ciências e Engenharia (FEBRACE) 5 . Os demais discentes dos anos

4 Este artigo contribui para as investigaçôes científicas desenvolvidas no grupo de pesquisa Práticas de Linguagens - PLES (UFT/CNPq).

5 "A Feira Brasileira de Ciências e Engenharia é um movimento nacional de estímulo ao jovem cientista, que todo ano realiza na Universidade de Săo Paulo uma grande mostra de projetos. A FEBRACE assume 
finais do Ensino Fundamental e do Ensino Médio também podem inscrever as próprias pesquisas na FEBRACE. Em todas essas situaçôes, os alunos também compartilham os resultados da pesquisa com a comunidade năo escolar ${ }^{6}$.

O projeto da FECIT é uma iniciativa da Secretaria Municipal de Educaçăo (SEMED) e da Secretaria de Desenvolvimento Econômico e Emprego (SEDEM), com o apoio de instituiçōes de ensino superior e outros parceiros. Enfatiza especialmente a iniciaçăo científica de docentes e discentes nas escolas municipais, por intermédio de edital público. Também podem se inscrever para apresentaçâo de trabalhos discentes do Ensino Fundamental, Ensino Médio, Educaçăo de Jovens e Adultos (EJA), Técnico ou Integrado ao Ensino Superior, matriculados em quaisquer instituiçóes públicas ou privadas de ensino, localizadas no território tocantinense?

Este artigo está organizado em três principais seçôes, além desta Introduçâo, das Consideraçōes finais e das Referências. Em Que sâo gêneros discursivos?, apresentamos uma breve discussăo teórica a respeito de algumas noçôes teóricas de gêneros discursivos e de letramento científico, retomadas na análise dos dados desta pesquisa. Em Quais foram os gêneros discursivos utilizados?, identificamos alguns gêneros produzidos pelos alunos da escola básica em atividades de iniciaçăo científica, salientando ainda as funçôes desempenhadas pelos referidos gêneros no contexto escolar. Finalmente, em Como sâo apropriados os gêneros discursivos?, descrevemos algumas práticas da cultura escolar na elaboraçấo de pôsteres científicos, resultando na produçăo de gêneros híbridos.

\section{QUE SÃO GÊNEROS DISCURSIVOS?}

Toda prática interativa em que nos inserimos em diferentes domínios sociais é mediada por algum gênero discursivo, nas diferentes modalidades de manifestaçáo da linguagem, a exemplo da oralidade e da escrita. Palestras e relatórios săo exemplos de gêneros utilizados por pesquisadores, no domínio científico, para divulgar e prestar conta das atividades investigativas realizadas, respectivamente. Numa perspectiva discursiva, de acordo com Fairclough (2012, p. 95), "gêneros sâo formas diversas de agir, de produzir vida social, no modo semiótico". Utilizando-nos das palavras de Bakhtin (2003, p. 281), destacamos que é "com os gêneros do discurso que relacionaremos as variadas formas de exposiçâo científica" (itálico acrescentado).

um importante papel social incentivando a criatividade e a reflexăo em estudantes da educaçăo básica, através do desenvolvimento de projetos com fundamento científico, nas diferentes áreas das ciências e engenharia" (Fonte: 〈http://febrace.org.br/o-que-e-a-febrace/\#.VyucjvkrLIU 〉; Acesso em 13 de fevereiro 2018.) ipsis verbis

6 De acordo com Bertoldo e Cunha (2016, p. 299), “as atividades realizadas pelos estudantes vâo além do que geralmente é trabalhado em sala de aula, ou seja, incluem conhecimentos práticos, técnicos que, até entâo, nâo eram relacionados como contexto dos estudantes e da audiência da feira. Quando o estudante/ expositor mostra os resultados do seu trabalho, ele atua como um divulgador da ciência, difundindo conhecimento técnico e científico para o público 'leigo'".

7 Na primeira ediçăo da FECIT, em 2014, foram inscritos 48 projetos, posteriormente, em 2015, foram inscritos 69 projetos de alunos matriculados em escolas públicas e particulares de Palmas, entretanto, a maioria dos inscritos pertenciam à rede municipal de ensino. Na última ediçáo da FECIT, em 2017, foram inscritos 71 projetos, incluindo aí alguns do ensino superior. 
Numa perspectiva pragmática, utilizamo-nos das noçóes de sistema de gênero e de sistema de atividade, propostas por Bazerman (2011) para compreender como os textos organizam as diferentes atividades interativas do cotidiano. O primeiro corresponde aos conjuntos de gêneros utilizados com alguma estabilidade por grupos de pessoas que interagem cooperativamente em funçăo de propósitos comuns. A identificaçăo ou mapeamento do sistema de gêneros possibilita a caracterizaçăo do sistema de atividades orientadas pelos gêneros utilizados no trabalho desempenhado pelo grupo de pessoas, uma vez que, materializados em textos, os gêneros orientam e realizam as práticas sociais. Daí a afirmaçăo de que "os gêneros emergem nos processos sociais em que pessoas tentam compreender umas às outras suficientemente bem para coordenar atividades e compartilhar significados com vistas a seus propósitos práticos" (BAZERMAN, 2011, p. 31).

Conforme Bazerman (2011, p. 35), "levar em consideraçâo o sistema de atividades junto com o sistema de gêneros é focalizar o que as pessoas fazem e como os textos ajudam as pessoas a fazê-lo", pois cada atividade humana tem um foco preciso, dependente do domínio ou esfera social e, ainda, mais especificamente, dos contextos de cultura e da situaçăo enunciativa propriamente dita. Ainda nos utilizando das palavras do autor, "quando você aprende a ler e usar artigos científicos do seu campo de estudo, você está sendo atraído por um modo profissional de ser e de trabalhar" (BAZERMAN, 2011, p. 31). Da mesma forma, quando instituiçōes de ensino criam situaçōes de aprendizagem que familiarizam os alunos com práticas investigativas de diferentes áreas do conhecimento, envolvendo ainda atividades mediadas pela escrita, o letramento científico dos envolvidos é trabalhado.

Uma atividade de linguagem, instaurada em meio às práticas escolares de leitura, produçấo textual e análise linguística, envolvendo o uso de gêneros discursivos variados, é a retextualizaçăo. Conforme Dell'Isola (2007, p. 26), é compreendida como "a refacçấo ou a reescrita de um texto para outro, ou seja, trata-se de um processo de transformaçâo de uma modalidade textual em outra, envolvendo operaçôes específicas de acordo com o funcionamento da linguagem".

A retextualizaçâo é realizada espontaneamente pelos usuários da língua em diferentes situaçōes interativas, a exemplo das exposiçōes orais em seminários científicos, realizadas a partir do conteúdo registrado em relatório ou artigo científico ${ }^{8}$. Esse caso corresponde náo apenas à readequaçấo textual entre as modalidades escrita e falada da língua, mas, também, a produçâo de outro gênero na oralidade a partir da escrita científica. Quando planejada de forma produtiva numa sequência de atividades de ensino ou num projeto de letramento, a retextualizaçâo pode se configurar como uma estratégia pedagógica diferenciada para minimizar a escolarizaçấo das práticas de produçấo textual no contexto escolar.

8 Nos termos de Marcuschi (2001, p. 48), "atividades de retextualizaçăo săo rotinas usuais altamente automatizadas, mas nâo mecânicas, que se apresentam como açōes aparentemente náo-problemáticas, já que lidamos com elas o tempo todo nas sucessivas reformulaçôes dos mesmos textos numa intrincada variaçăo de registros, gêneros textuais, níveis linguísticos e estilos. Toda vez que repetimos ou relatamos o que alguém disse, até mesmo quando produzimos as supostas citaçôes ipsis verbis, estamos transformando, reformulando, recriando e modificando uma fala em outra". 
Numa perspectiva mais ampla, concordamos com Soares (2001), ao afirmar que o letramento é essencialmente um conjunto de práticas socialmente construídas que envolvem a leitura e a escrita. Sendo assim, a escola precisa compreender o letramento numa dimensăo social mais produtiva, envolvendo muito mais que as tradicionais práticas escolares de leitura e escrita para a escola, quando o professor é o único interlocutor 'interessado' nas atividades desenvolvidas pelos alunos. Essas práticas pedagógicas resultam no que denominamos de escolarizaçăo improdutiva do letramento, caracterizada por práticas de leitura e de escrita com fins excessivamente didáticos, a exemplo do aprendizado da gramática normativa em aulas de língua ou, ainda, de algum outro conteúdo disciplinar legitimado pela tradiçáo escolar. Nessa perspectiva, enquanto os eventos de letramento sâo direcionados para a aquisiçăo de conteúdos gramaticais em aulas de Língua Portuguesa ${ }^{9}$, conteúdos disciplinares diversos, legitimados como bens culturais, também sâo aferidos a partir de eventos de letramento em outras disciplinas escolares.

No espaço escolar, as atividades de iniciaçâo científica se configuram em estratégias pedagógicas em que os usos da tecnologia da escrita podem se tornar mais produtivos, pois os alunos sâo inseridos em situaçôes interativas em que podem apreender outras funcionalidades para as práticas de leitura e escrita, indo além da interlocuçáo mais simplificada com o professor. Ou seja, atividades diferenciadas de linguagem sâo realizadas por propósitos instaurados ao longo do processo de pesquisa.

Em meio a estudos acadêmicos a respeito do ensino das ciências naturais na escola básica, consolida-se o campo de estudos nâo disciplinar do letramento ou alfabetizaçâo científica (cf. CHASSOT, 2003; SANTOS, 2007; SASSERRON; CARVALHO, 2008). Por considerar a dimensăo social da escrita em atividades científicas, o termo letramento científico está presente na literatura acadêmica a respeito da educaçâo científica. Conforme Santos (2007, p. 479), o letramento científico é utilizado para "enfatizar a funçăo social da educaçáo científica contrapondo-se ao restrito significado de alfabetizaçăo escolar". Ainda conforme Santos (2007, p. 480) "o letramento dos cidadăos vai desde o letramento no sentido do entendimento de princípios básicos de fenômenos do cotidiano até a capacidade de tomada de decisâo em questóes relativas à ciência e tecnologia".

A iniciaçâo científica, também denominada por alguns estudiosos de alfabetizaçăo científica ${ }^{10}$, a exemplo de Sasseron e Carvalho (2008, p. 335) deve ser efetivada em três eixos estruturantes: "(1) compreensâo básica de termos, conhecimento e conceitos científicos para entender informaçôes e situaçôes cotidianas; (2) compreensâo da natureza da ciência e dos fatores éticos e políticos que circundam sua prática; (3) entendimento das relaçóes existentes entre ciência, tecnologia, sociedade e meio-ambiente" (itálico do original). Esses eixos precisam permear as práticas pedagógicas na perspectiva da familiarizaçāo discente com o letramento científico, nâo se limitando

9 Sobre o trabalho com conteúdo gramatical na escola, destacamos a perspectiva científica para o estudo da gramática, quando os alunos săo orientados a analisar/pesquisar a estrutura da língua, conforme pontuado por Antunes (2017). Essa perspectiva é pouco conhecida e demanda pesquisas acadêmicas no viés dos estudos do letramento científico.

10 A iniciaçâo científica é denominada de Alfabetizaçăo Científica por alguns estudiosos, dentre os quais mencionamos Demo (2011) e Chassot (2003). Conforme os autores, a alfabetizaçáo científica pode potencializar alternativas que privilegiam uma educaçăo mais comprometida com a formaçăo cidadă. 
ao que Bertoldo e Cunha (2016, p. 297) denominam de "enculturaçăo científica", mas procurando minimizar a reproduçăo despropositada de conteúdos escolares e, por outro lado, promovendo uma educaçăo mais sustentável, logo, minimamente, mais crítica, duradoura e profunda (cf. HARGREAVES; FINK, 2007; SILVEIRA, 2016).

\section{QUAIS FORAM OS GÊNEROS DISCURSIVOS UTILIZADOS?}

Na escola municipal focalizada nesta pesquisa, procura-se desenvolver a iniciaçăo científica dos alunos de forma dinâmica e cooperativa. As atividades săo realizadas mediante interaçấo entre os próprios alunos sob a mediaçâo de um professor, que é responsável por coordenar os trabalhos de pesquisa de uma turma. É facultada aos alunos de cada equipe a escolha de outro professor como coorientador. Nesse sentido, cada profissional pode se envolver com trabalhos desenvolvidos em outras turmas diferentes da qual é responsável. As pesquisas săo elaboradas em equipes preferencialmente compostas por até três alunos e cada membro do grupo possui uma funçâo, conforme podemos evidenciar no excerto do Diário de Bordo, reproduzido no Exemplo 1 , elaborado por um dos alunos em funçâo das feiras científicas escolares ${ }^{11}$.

\section{Exemplo 1 - Diário de Bordo}

04-06-2014 - O grupo se reuniu na sala dos professores para discutir sobre que projeto e deveres de cada um do grupo. Ficou definido que o aluno X elaboraria eu pesquisaria sobre que projeto seria executado, o aluno Y faria o diário de bordo, já os demais alunos trariam os materiais para a construçăo do projeto e ajudariam no sentido de se prepararem para responder sobre. (D - 01 Motor Eletromagnético)

O sistema de gênero que organiza as atividades de iniciaçăo científica nas escolas municipais é formado por: artigo; cartaz; debate; diário de bordo; dossiê; entrevista; exposiçăo oral; gráfico; ficha de inscriçăo, mensagem eletrônica; formulário; lista; maquete; orçamento; projeto de pesquisa; questionário; relatório; reportagem escrita e televisiva; resumo; vídeo; dentre outros.

O diário de bordo, projeto, relatório e resumo săo gêneros discursivos exigidos em editais de inscriçōes das feiras científicas escolares. O diário de bordo fica sempre em porte dos alunos para registrar experiências, feitos ou atividades diversas que julgam necessárias para compartilhar em outras situaçōes, a exemplo dos estandes expositivos das feiras científicas escolares. O relatório é utilizado pelos alunos para apresentar ao professor da turma uma pesquisa bibliográfica a respeito da temática que desejam investigar. Esse uso pode ser evidenciado no seguinte excerto de um diário de bordo: “No dia 16/05/2014 nos reunimos para escolhermos o trabalho para a feira de ciências.

11 Todos os registros de pesquisa foram transcritos a título de ilustraçâo conforme os originais, ou seja, nâo realizamos adequaçóes linguísticas de tipo algum. Apenas omitimos a identificaçâo dos atores sociais envolvidos nas atividades escolares, evitando, assim, algum tipo de exposiçáo indevida da comunidade escolar. 
Nesta reuniâo escolhemos pesquisar sobre a casca da cebola. Daí fizemos um relatório de acordo com o assunto" (D - 02 Cebola Poderosa; itálico acrescentado).

$\mathrm{Na}$ composiçăo do sistema de atividades desencadeado pelas feiras científicas escolares, os alunos realizaram algumas atividades de retextualizaçâo, ou seja, utilizaram-se do conteúdo de um texto por eles previamente elaborado para produzirem outro texto, configurado em outro gênero em resposta a uma demanda diferenciada de produçăo textual. O diário de bordo, por exemplo, possibilitou o registro de conteúdos necessários à elaboraçáo do projeto de pesquisa, que, por sua vez, orientou uma série de açôes sintetizadas na escrita do artigo científico. A retextualizaçâo desse último resultou na confecçâo do pôster científico. Esses diferentes gêneros săo produzidos em funçăo das atividades tipificadas para contextos situacionais precisos, especialmente caracterizados por objetivos e interaçôes pontuais.

O projeto de pesquisa é utilizado para informar atividades futuras, em desenvolvimento ou, até mesmo, realizadas, a instituiçôes responsáveis pela organizaçăo das feiras científicas escolares, envolvendo aí o papel desempenhado por comissōes avaliadoras. Entre os projetos de pesquisa inscritos na FECIT, alguns estavam em fase de desenvolvimento, ao passo que outros já estavam finalizados, a exemplo do projeto de pesquisa "O trânsito, a criança e a escola: uma parceria de sucesso", desenvolvido por alunos do $9^{\circ}$ ano, que elaboraram um jogo educativo para crianças de $4^{\circ}$ e $5^{\circ}$ anos.

Artigos científicos sâo elaborados pelos alunos que se inscreveram na FEBRACE. A produçâo desses textos é uma exigência para os alunos poderem participar da feira. Os artigos ficam arquivados na base de dados da feira científica escolar. Já os pôsteres e diários de bordo sáo disponibilizados por algum momento em exposiçôes de trabalhos científicos. O pôster científico expóe o trabalho de modo sintético, ao passo que o diário de bordo apresenta detalhadamente as atividades de desenvolvimento da pesquisa.

No Quadro 1, reproduzimos figuras ilustrativas de alguns textos de diferentes gêneros utilizados nas práticas pedagógicas de iniciaçăo científica na escola focalizada nesta pesquisa. Os textos circulam em diferentes suportes, como o simples papel para notas, estande expositivo, computador e aparelho telefônico.

Na Figura 1, visualizamos alunos da EJA entrevistando duas pessoas numa praça pública localizada na frente da escola. A imagem nâo nos permite identificar com precisâo o texto utilizado como suporte para realizaçáo da entrevista, mas, certamente, tratava-se do uso de questionário ou roteiro para uma entrevista mais espontânea. Como sabemos, a entrevista possibilita a exposiçâo de informaçōes por colaboradores da pesquisa científica, sendo os dados gerados passíveis de confrontaçăo com outros registros de pesquisa produzidos. A partir do processo de retextualizaçấo, o conteúdo da entrevista pode ser transformado em tabelas ou gráficos, após análise quantitativa dos dados. 
Quadro 1 - Interaçóes mediadas por diferentes gêneros discursivos

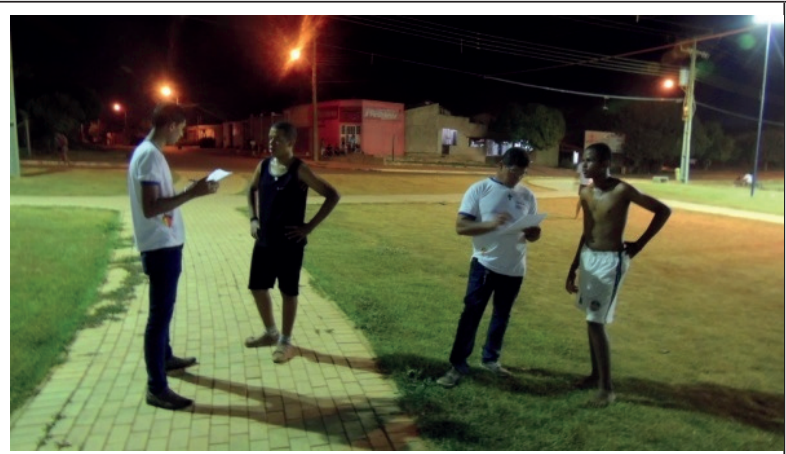

Figura 1: Alunos da EJA Realizando Entrevistas (2015)

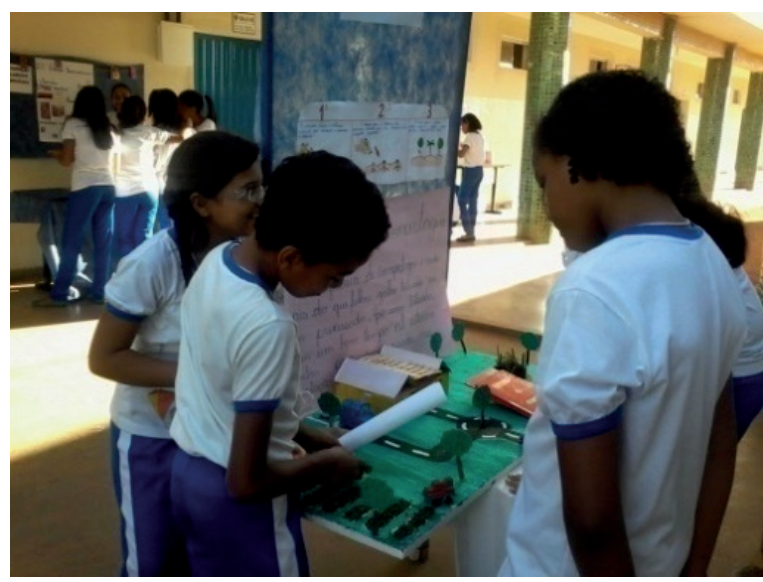

Figura 3: Exposiçăo da pesquisa - Feira cientifica escolar (2014)

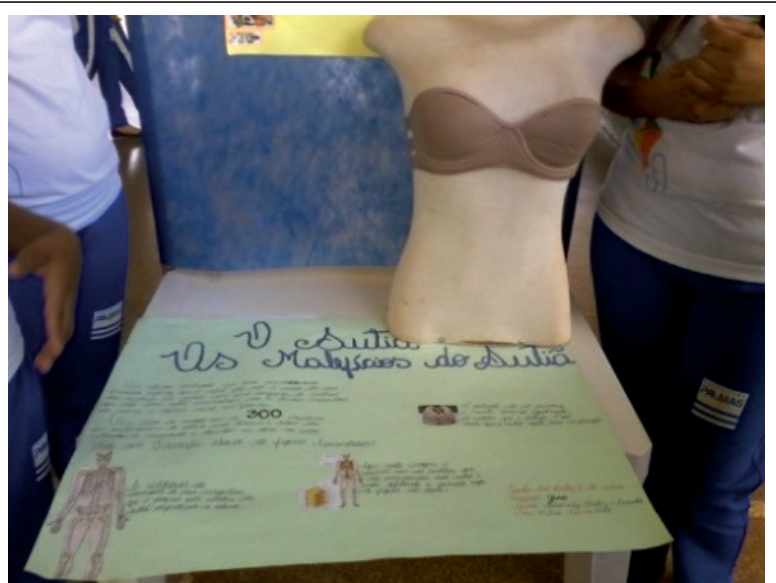

Figura 5: Cartaz de apresentaçăo da Pesquisa Feira cientifica escolar (2014)

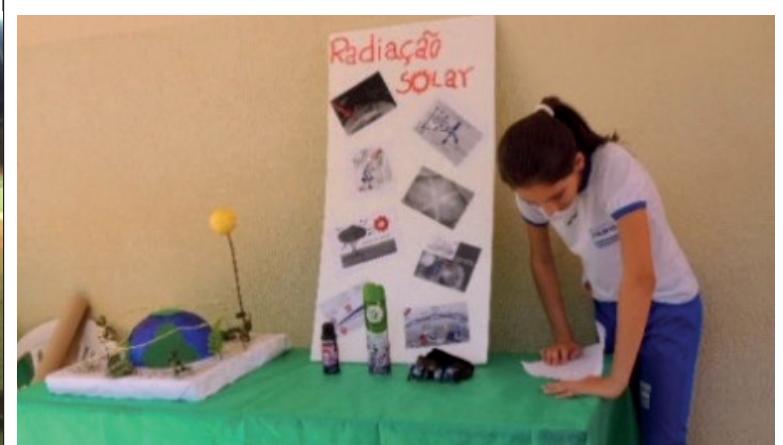

Figura 2: Aluna lendo roteiro de fala antes da Exposiçăo Oral - Feira científica escolar (2014).

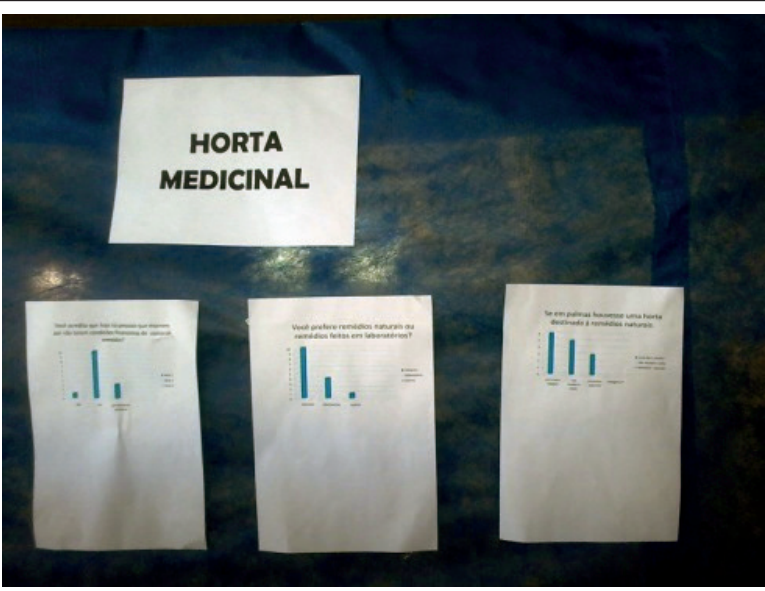

Figura 4: Representaçáo gráfica de resultado de entrevista com a comunidade - Feira cientifica escolar (2014)

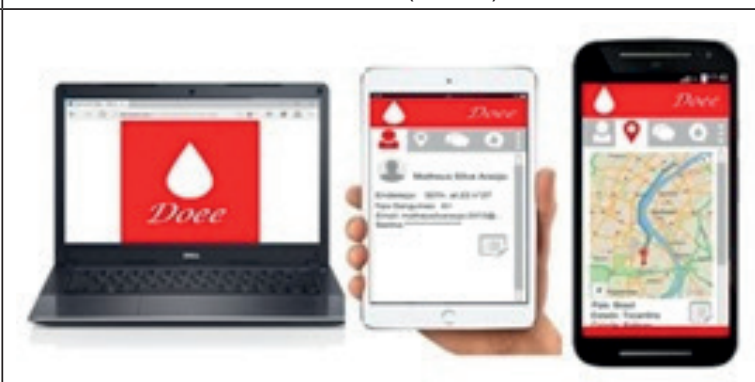

Figura 6: Aplicativo para facilitar a comunicaçăo entre doadores e receptores de sangue - FEBRACE (2016). 
Na Figura 2, encontramos uma maquete, um mosaico de fotos a respeito da radiaçâo solar, além de uma aluna lendo, provavelmente, algum resumo, anotaçáo ou roteiro para auxiliar na exposiçâo oral durante a feira científica escolar. Nessas situaçôes interativas, quase sempre, a comunicaçâo oral é mediada pela escrita, podendo resultar no desenvolvimento do uso adequado de diferentes linguagens, inclusive a gestual.

Na Figura 3, há alguns alunos interagindo. Um deles segura uma folha de papel, que pode trazer algum texto orientador da exposiçáo oral realizada na ocasiăo. A Figura 4 ilustra o uso de gráficos integrantes do sistema de atividades de iniciaçăo científica.

A maquete e o cartaz também funcionam como instrumentos mediadores da produçăo expositiva oral. Na maquete, os alunos representaram a horta comunitária da quadra vizinha à escola, a Praia das Arnos, localizada próxima à instituiçâo, dentre outros espaços públicos. Pela característica tridimensional, a maquete representa cenas e cenários diversos e possibilita visualizar todo o conjunto espacial.

O cartaz é bastante utilizado na escola, uma vez que auxilia os alunos nas exposiçóes orais durante seminários temáticos. Na feira científica escolar, além de mediar diretamente a exposiçâo oral do aluno, o cartaz informa de maneira mais clara e sucinta a pesquisa realizada pelos discentes. Na Figura 5, por exemplo, há informaçóes compostas por enunciados curtos e desenhos. Nos dois primeiros parágrafos do referido cartaz, encontramos o texto reproduzido no Exemplo 2, que, infelizmente, corresponde a um texto disponibilizado na Internet ${ }^{12}$.

\section{Exemplo 2 - Excerto de Cartaz}

Um estudo realizado em uma universidade francesa afirma que o sutiă faz mal para a saúde dos seios das mulheres. De acordo com uma pesquisa, as mulheres que năo usam sutiă desenvolvem mais os tecidos musculares da mama e sofrem menos com a flacidez.

Além disso de acordo com as 300 mulheres que participaram do estudo após tirarem o sutiâ, elas melhoraram na respiraçăo e também nas dores nas costas.

Veja um Exemplo abaixo, nas figuras Apresentadas:

A prática de cópia revela a necessidade do acompanhamento mais efetivo das atividades pelo professor orientador da pesquisa, de forma que possa garantir a construçăo do conhecimento a partir do fortalecimento do letramento digital ${ }^{13}$ dos alunos, que, apesar de estarem, de alguma maneira, inseridos no mundo

12 Disponibilizamos aqui o endereço em que encontramos o texto reproduzido o Exemplo 2: 〈http://www. bemestarmed.com.br/site/pesquisa-afirma-que-sutia-faz-mal-a-saude-da-mulher/>. Acesso em: 21 abr. 2016.

13 De acordo com Ribeiro (2009, p. 30), "letramento digital é a porçâo do letramento que se constitui das habilidades necessárias e desejáveis desenvolvidas em indivíduos ou grupos em direçáo à açâo e à comunicaçâo eficientes em ambientes digitais" (itálico do original). 
digital, precisam aprender a fazer usos mais produtivos das mídias digitais, evitando, por exemplo, a apropriaçáo indevida de textos alheios, o que se configura como uma forma difer enciada da antiga prática de cópia propagada pela cultura escolar ${ }^{14}$. As atividades de iniciaçấo científica precisam funcionar como experiências modelares de instruçăo do aluno na escola básica, pois podem servir de referência em oportunidades futuras na vida desse cidadâo.

Quase sempre, os alunos realizam por conta própria as atividades escolares de iniciaçáo à pesquisa, conforme podemos evidenciar nos três excertos do Exemplo 3, ilustrativos de algumas entrevistas que realizamos com alguns professores da escola municipal. As justificativas das professoras, para a precária orientaçăo dos alunos, giram em torno das condiçôes adversas de trabalho docente, envolvendo infraestrutura, excesso de alunos por turma, ausência de tempo, dentre outras. A essas justificativas, acrescentamos a formaçáo precária do professor para desenvolvimento de atividades de pesquisa científica na área específica de atuaçăo profissional.

\section{Exemplo 3 - Entrevista com Professores}

Os alunos pesquisam praticamente sozinhos, quando săo selecionados para apresentarem na FECIT, passamos a orientar melhor. (P1)

Todos os alunos da escola têm que participar. Sáo doze projetos por sala.É complicado, como é fundamental, você náo tem a liberdade, um tempo maior para orientar os alunos, porque é diferente de professor universitário que tem tempo para pesquisa, para ministrar as aulas. (P2)

Eu vejo a feira como algo muito positivo. Às vezes, o que eu acho que atrapalha é porque, por exemplo, no ano passado, tivemos a feira no final do mês de junho que é época de fechamento de notas, de avaliaçōes. (P3)

Após serem selecionados para participaçăo na FECIT, há uma tendência de fortalecimento da orientaçăo dos alunos, pois, ao lidar com um quantitativo mais reduzido de discentes, o professor consegue administrar melhor o tempo e as atividades profissionais. Os registros de diários de bordo, reproduzidos no Exemplo 4, certamente, também refletem essa mudança nas situaçōes interativas após seleçăo dos trabalhos para o evento municipal.

14 De acordo com Gee e Hayes (2011, p. 1), “as mídias digitais sâo um híbrido interessante das propriedades das linguagens oral e escrita. Os leitores certamente dizem que a media digital carrega muito mais que linguagem. Mas a linguagem é e tem sido sempre uma mistura de som, palavras, imagens criadas na mente e gestos usados em contextos cheios de objetos, sons, açóes e interaçôes. 


\section{Exemplo 4 - Diário de bordo}

No dia 10/06/2014 tivemos a quinta reuniâo onde fizemos a pesquisa sobre átomo de hidrogênio.

O átomo é um sistema energicamente estável, formado por um núcleo positivo que contém nêutrons e prótons e cercado de elétrons, a menor quantidade de uma substancia elementar que tem as propriedades químicas de um elemento ( $D$ - 02 Cebola Poderosa).

No dia 08/06/2015, pesquisamos sobre a classificaçăo química e principais funçōes dos fitoesteróis. [...] Os fitoesteróis sāo naturalmente presentes nas plantas, encontra-se em pequenas quantidades. Apresentam-se sob a forma de pó branco, sendo insolúveis na água mas solúveis no álcool (https: PT.wikipedia.org/wiki/fitoesterol) D - 02 Cebola Poderosa).

No dia 09 de junho nos reunimos para pesquisarmos. Acabamos pesquisando sobre a biossintese dos fitoesterois. Vemos que ocorre através da via meta bolica que tem início na reduçấo da hidroxi-metilglutaril coenzima A (HMG-COA) ao mevalonato (YANKAH, 2006) [...] (D - 02 Cebola Poderosa)

No Exemplo 4, o primeiro excerto corresponde à pesquisa desenvolvida pelos alunos antes da apresentaçâo na feira científica escolar, trata-se de uma cópia de texto disponível na internet ${ }^{15}$. O segundo e o terceiro foram produzidos na segunda fase da pesquisa, no ano de 2015, após as apresentaçôes nas feiras ciências da escola, da FECIT e da FEBRACE. Algumas pesquisas do alunado săo desenvolvidas em dois anos consecutivos, quando uma pesquisa carece de mais estudos e sâo apresentadas em feiras extraescolares.

No segundo excerto do Exemplo 4, os discentes fazem referência ao site pesquisado e, no terceiro, referenciam o autor das passagens textuais transcritas para o diário, mesmo ainda náo se utilizando das aspas como recursos metaenunciativos. Esses excertos evidenciam a assimilaçăo de prática do letramento científico pelos alunos, mostrando a relevância da continuidade das atividades de iniciaçăo científica nas escolas.

Retomando o Quadro 1, na Figura 3, há um infográfico manual que demonstra as etapas da realizaçáo do processo de compostagem, representadas por recursos verbais e năo verbais. Em computaçăo gráfica, a infografia é a apresentaçăo impressa ou em formato digital do binômio texto/imagem (DE PABLOS, 1998). Na Figura 6, há uma imagem de um aplicativo denominado "DOEE", elaborada pelos alunos por intermédio de recursos infográficos. O aplicativo se constitui como um meio de interaçấo multimodal para atingir doadores de sangue e instituiçóes receptoras ${ }^{16}$.

\footnotetext{
15 Disponibilizamos o link do site onde está disponível texto copiado: <https://br.answers.yahoo.com/ question/index?qid=20111108084146AARGIDi >. Acesso em: 24 abr. 2016.

16 Modelização é um conceito semiótico no campo da informática para descrever a ocorrência de linguagem em sistemas,
} 
A imagem com três aparelhos tecnológicos (computador, tablet e celular) da Figura 6, apresentada no relatório enviado à FEBRACE, estava acompanhada da seguinte legenda: "Figura 5: Demonstraçâo do aplicativo desenvolvido para facilitar a comunicaçâo entre doadores e receptores sanguíneos" (Palmas, 2014b, p. 24). Imagem e legenda indicam que o aplicativo pode ser instalado nos três aparelhos, mostram acessibilidade e agilidade do aplicativo, pois pode ser instalado em quaisquer dos aparelhos com acesso à Internet, o que facilita a comunicaçấo entre doadores e receptores de sangue.

\section{COMO SÃO APROPRIADOS OS GÊNEROS DISCURSIVOS?}

As atividades de iniciaçâo científica analisadas foram caracterizadas pelo maior ou menor impacto sofrido por parte da cultura escolar. Nesta seçâo, analisamos dois pôsteres científicos escolares com resultados de pesquisas distintas, desenvolvidas por alunos da instituiçăo focalizada. Esse gênero deveria possibilitar o compartilhamento de resultados da efetiva atividade investigativa desenvolvida pelos alunos. A materialidade textual dos pôsteres investigados traz evidências diferenciadas da interferência da cultura escolar sobre a produçăo textual dos alunos.

Na Figura 7, evidenciamos uma atividade bastante influenciada pela escolarizaçăo dos gêneros discursivos, daí utilizarmos aqui a denominaçăo Pôster Científico Escolar.

construídos com a diversidade de signos icônicos de plasticidade visual ou com os signos cinéticos do mundo audiovisual dos meios de comunicação (cf. MACHADO, 2016). Ainda conforme Machado (2016, p. 124), "o argumento gráfico sintetiza possibilidades de articulação do pensamento em raciocínio semioticamente manifestado". 
Figura 7 - Projeto: "Suco de Noni e Uva: prevençăo e auxílio no tratamento de tumores malignos"

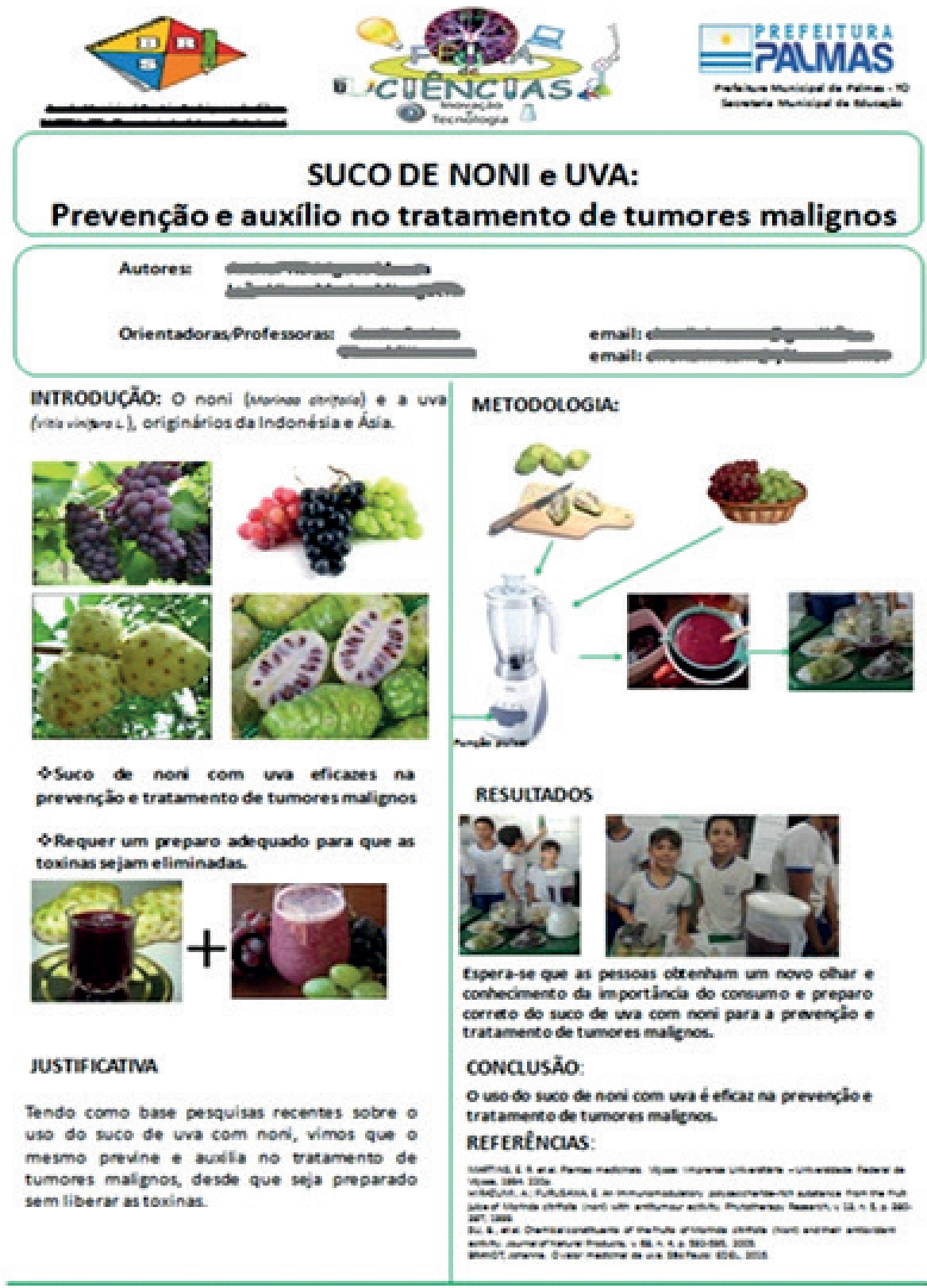

Fonte: Pôster cedido por uma escola municipal de Palmas (TO)

No texto, săo valorizados aspectos formais e visuais, em detrimento do conteúdo escrito elaborado pelos próprios alunos. Esse conteúdo corresponde a uma espécie de síntese de informaçôes a respeito das propriedades do suco produzido a partir do noni e da uva. Ou seja, a pesquisa realizada pelos alunos estava restrita à revisâo bibliográfica da literatura especializada a fim de convencer os interlocutores a respeito dos benefícios das frutas. De alguma forma, os alunos reproduziram uma tese defendida em 
várias páginas eletrônicas, inclusive no blog denominado 'Suco Nonimix'17. Defendem a tese de que o suco das referidas frutas previne doenças, também ensinam como produzir o suco mencionado.

No Pôster Científico Escolar, muitas imagens săo utilizadas com funçăo decorativa, como as duas fotografias de alunos dispostas na seçâo Resultados. Certamente, essa forma mais simplificada de apropriaçấo do gênero se justifique pela pouca maturidade dos alunos matriculados num $4^{\circ}$ Ano do Ensino Fundamental I. A pesquisa na escola deve ir além da reproduçâo de informaçóes: "alunos e professores devem ser capazes de produzir conhecimento próprio, usando a metodologia científica, exercitando suas habilidades de argumentaçâo e fundamentaçăo" (Demo, 2011, cp). Ao ser familiarizado com atividades de iniciaçăo científica, o aluno precisa aprender a elaborar individual ou coletivamente textos, inclusive, multimodais, com desenvoltura e qualidade, possibilitando a fácil compreensăo do conteúdo pelo leitor interessado.

O pôster da Figura 7 traz uma hibridizaçăo de práticas características de diferentes instituiçōes. Há algumas imagens de frutas repetidas e intercaladas a frases soltas, o que é bastante comum nas produçôes textuais dos alunos matriculados nos anos iniciais da escola básica. $\mathrm{O}$ uso das imagens parece escapar às convençôes dos recursos visuais no pôster científico, os quais, além de atrair a atençăo do leitor, servem para ilustrar experimentos, objetos investigados, etapas da pesquisa etc.

No pôster científico escolar exemplificado, nâo há conexâo explícita nas frases apresentadas na Introduçáo (Suco de noni com uva eficazes na prevençâo e tratamento de tumores malignos. / Requer um preparo adequado para que as toxinas sejam eliminadas.). A Metodologia deveria enunciar as etapas caracterizadoras do desenvolvimento do trabalho e năo apenas as etapas de preparo do suco de frutas. Em Resultados, deveriam ser explicitados os resultados finais ou parciais da pesquisa e náo a expectativa compartilhada pelos alunos no tocante à reaçăo dos interlocutores interessados nas propriedades do suco de frutas (Espera-se que as pessoas obtenham um novo olhar e conhecimento da importância do consumo e preparo correto do suco de uva com noni para a prevençâo e tratamento de tumores malignos). A conclusáo apresentada náo foi produzida pelos alunos, mas compreendemos que, inicialmente, foi apresentada como uma tese a ser comprovada ( 0 uso do suco de noni com uva é eficaz na prevençáo e tratamento de tumores malignos).

Nesse sentido, destacamos adiante os conteúdos focalizados em cada seçáo, os quais, com exceçâo das referências, năo se adequam ao modelo do gênero compartilhado no domínio científico. No Quadro 2, apresentamos uma análise descritiva e comparativa do que evidenciamos no pôster científico da Figura 1 e do modelo do gênero por nós compartilhado.

17 O blog além de informar sobre os benefícios do suco para a saúde, ainda disponibiliza a venda do suco de noni com uva. Consultar em: 〈http://sucononimix.blogspot.com.br/〉. Acesso em: 20 fev. 2018. 
Quadro 2: Realizaçăo do pôster científico

\begin{tabular}{|c|c|}
\hline PÔSTER CIENTÍFICO ESCOLAR & PÔSTER CIENTÍFICO \\
\hline $\begin{array}{l}\text { Introduçăo: săo sintetizadas } \\
\text { informaçóes sobre a origem das fru- } \\
\text { tas tematizadas, a eficácia do suco } \\
\text { produzido e o preparo adequado dos } \\
\text { frutos para ingestáo; }\end{array}$ & $\begin{array}{l}\text { Introduçáo: apresenta, de maneira clara } \\
\text { e concisa, informaçóes referentes à pesquisa: } \\
\text { o problema, a(s) pergunta(s), a(s) hipótese(s), } \\
\text { a(s) justificativa(s) e os objetivos em lingua- } \\
\text { gem verbal; }\end{array}$ \\
\hline $\begin{array}{l}\text { Justificativa: sâo compartilha- } \\
\text { dos benefícios do suco das frutas } \\
\text { mencionadas, conforme resultados } \\
\text { produzidos em pesquisas utilizadas } \\
\text { como referências pelos alunos; }\end{array}$ & $\begin{array}{l}\text { Justificativa: informar a relevância da } \\
\text { pesquisa, apresentando alguma demanda } \\
\text { convincente para justificar o desenvolvi- } \\
\text { mento da pesquisa, seja do ponto de vista } \\
\text { teórico ou prático; }\end{array}$ \\
\hline $\begin{array}{l}\text { Metodologia: sáo dispostas al- } \\
\text { gumas imagens aludindo ao preparo } \\
\text { do suco, lembrando-nos do gênero } \\
\text { receita culinária; }\end{array}$ & $\begin{array}{l}\text { Metodologia: contém explicitaçôes e } \\
\text { explicaçôes sobre o que foi pesquisado e os } \\
\text { procedimentos metodológicos desenvolvi- } \\
\text { dos conforme o problema investigado; }\end{array}$ \\
\hline $\begin{array}{l}\text { Resultados: é explicitada a ex- } \\
\text { pectativa dos alunos no tocante ao } \\
\text { discernimento dos interlocutores } \\
\text { sobre os benefícios do suco das fru- } \\
\text { tas, após esclarecimentos realizados } \\
\text { pelo trabalho da equipe; }\end{array}$ & $\begin{array}{l}\text { Resultados: descreve os resultados ob- } \\
\text { tidos com interpretaçōes do pesquisador. Se } \\
\text { for necessário, insere-se figuras, ilustraçōes, } \\
\text { quadros ou tabelas. Essas devem ser elabo- } \\
\text { radas conforme as normas de apresentaçāo } \\
\text { tabular (IBGE, 1993); }\end{array}$ \\
\hline $\begin{array}{l}\text { Conclusăo: é repetida a tese ini- } \\
\text { cial do trabalho a respeito da eficácia } \\
\text { das frutas para a saúde humana; }\end{array}$ & $\begin{array}{l}\text { Conclusáo: sintetiza a pesquisa reali- } \\
\text { zada. Os autores devem expor os resultados } \\
\text { obtidos, podendo até comparar aos resul- } \\
\text { tados de outras pesquisas. Sáo respondidos } \\
\text { explicitamente os objetivos ou perguntas de } \\
\text { pesquisa; }\end{array}$ \\
\hline $\begin{array}{l}\text { Referências: sāo apresentadas } \\
\text { referências brasileiras e estrangei- } \\
\text { ras de livros e periódicos científicos } \\
\text { especializados. }\end{array}$ & $\begin{array}{l}\text { Referências: tem como objetivo iden- } \\
\text { tificar a origem/fonte/autor das principais } \\
\text { referências utilizadas na pesquisa e, princi- } \\
\text { palmente, explicitadas no pôster científico. }\end{array}$ \\
\hline
\end{tabular}

Fonte: Autoria própria 
O pôster científico também pode conter opcionalmente um resumo do trabalho. Antes da introduçăo, o resumo deve apresentar sucintamente o tema abordado, o problema de pesquisa, a justificativa, a metodologia, o(s) objetivo(s), o resultado e a conclusăo, seguido de palavras-chaves e deve estar consoante com a Norma Brasileira (NBR) - 6028 da Associaçāo Brasileira de Normas Técnicas (ABNT) ${ }^{18}$. A norma da ABNT que regulamenta a confecçâo de pôster é a NBR 15437. As especificidades para a elaboraçăo das seçôes săo respaldadas em outras normas, a facçăo das tabelas, por exemplo, é regida pela Norma de apresentaçáo tabular do IBGE (1993).

Ilustraçôes, figuras, fotos, mapas, dentre outros textos multimodais, inseridos no corpo do pôster científico, devem conter a indicaçăo da fonte. As citaçóes devem ser inscritas conforme a NBR - 10520 da ABNT e as referências em concordância com a NBR - 6023 da ABNT.

Para fins comparativos, exemplificamos outro pôster científico escolar na Figura 8.

Figura 8 - Projeto Cebola poderosa

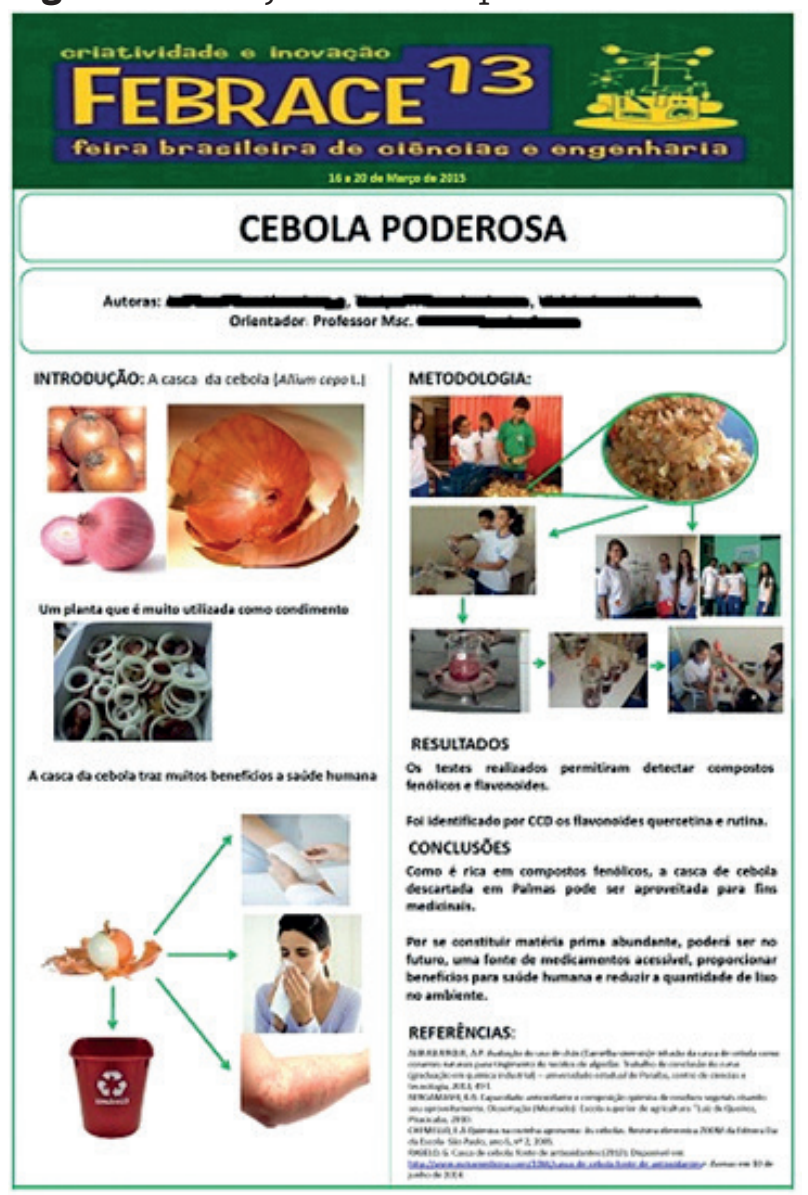

Fonte: Pôster cedido por uma escola municipal de Palmas (TO)

18 A Associaçāo Brasileira de Normas Técnicas (ABNT) é o órgăo responsável pela normalizaçăo técnica no Brasil, fornecendo a base necessária ao desenvolvimento tecnológico brasileiro. Trata-se de uma entidade privada e sem fins lucrativos e de utilidade pública, fundada em 1940. (Fonte: <https:// pt.wikipedia.org/wiki/Associa\%C3\%A7\%C3\%A3o Brasileira de Normas T\%C3\%A9cnicas/>; Acesso em 05 de março de 2018). 
Produzido por alunos do $9^{\circ}$ Ano, esse texto aparenta menor interferência da cultura escolar, que se mostra mais evidente nas fotografias utilizadas na metodologia, onde alunos e orientador sâo representados interagindo com a lente que os fotografa. Essas imagens salientam a presença dos alunos, desviando a ênfase no produto estudado.

Na Introduçâo, identificamos articulaçōes entre frases e imagens, evidenciando maior funcionalidade das imagens no conjunto do texto produzido. Na Metodologia, por exemplo, as imagens săo dispostas numa sequência responsável pela reconstruçăo da narrativa das etapas de desenvolvimento da pesquisa: (1) busca da casca da cebola em supermercado; (2) realizaçăo da pesquisa na escola; (3) realizaçăo da pesquisa no Laboratório de Pesquisa em Produtos Naturais, pertencente à Universidade Federal do Tocantins (UFT).

Os Resultados mostram os compostos químicos detectados a partir dos experimentos (Os testes realizados permitiram detectar compostos fenólicos e flavonoides. / Foi identificado por CCD os flavonoides quercetina e rutina.). A Conclusáo sintetiza o que foi averiguado na etapa final da pesquisa, salientado alguns benefícios a serem proporcionados à populaçáo (Como é rica em compostos fenólicos, a casca de cebola descartada em Palmas pode ser aproveitada para fins medicinais. / Por se constituir matéria prima abundante, poderá ser no futuro, uma fonte de medicamentos acessível, proporcionar benefícios para saúde humana e reduzir a quantidade de lixo no ambiente.). Por fim, assim como na Figura 7, esse último pôster científico escolar traz referências de textos acadêmicos, como livros e trabalhos de conclusăo de curso (TCC e dissertaçăo de mestrado).

As análises dos dados disponibilizados para esta pesquisa mostraram que a iniciaçáo científica na escola pode se configurar como uma estratégia pedagógica produtiva, familiarizando os alunos com sistemas de atividades característicos da prática científica. É preciso que haja um currículo escolar na perspectiva do letramento científico para "ressignificaçâo dos saberes científicos escolares que estâo sendo abordados de forma descontextualizada, com uma linguagem hermética, reproduzindo uma falsa imagem de ciência" (Santos, 2007, p. 485). Como qualquer outra estratégia pedagógica, inúmeros fatores condicionam a produtividade das atividades planejadas, a exemplo da motivaçấo dos alunos e da adequada formaçăo do professor para desenvolver um trabalho na perspectiva do letramento científico.

As professoras orientadoras do projeto que originou o texto da Figura 7 apenas possuem Licenciatura em Pedagogia. $O$ professor orientador da pesquisa que originou o texto da Figura 8 é licenciado em Ciências Biológicas, possui mestrado e, na ocasiâo da pesquisa, cursava doutorado dentro da grande área das Ciências Naturais. Esses dados mostram que as professoras foram preparadas para lecionar e, certamente, nâo tiveram preparo específico para a prática de investigaçăo científica; e o professor vem se especializando como pesquisador, além de ser conhecedor dos procedimentos para realizaçăo de estudos científicos na área de formaçăo. Quando retomamos os dados aqui analisados, arriscamo-nos em afirmar que, certamente, esse último profissional pode dar grande contribuiçăo aos projetos institucionais para desenvolver o letramento científico dos alunos da escola básica, corroborando, inclusive, com a capacitaçăo de outros professores da rede pública de ensino, que pouco podem fazer ao serem convocados para assumir novos desafios, sem preparo prévio e, até mesmo, sem condiçōes adequadas de trabalho. 


\section{CONSIDERAÇÕES FINAIS}

A análise dos dados mostrou que as atividades de iniciaçăo científica escolar podem instaurar práticas de linguagem diferenciadas na educaçăo básica, o que acontece por meio de interaçóes mediadas por gêneros discursivos tomados como modelos no sistema de atividades constitutivo do domínio científico. Observamos a produçấo de gêneros híbridos, ou seja, marcados por práticas sociais características de diferentes domínios sociais, sendo a cultura escolar a maior influenciadora.

A força impulsionadora da cultura escolar é alimentada por alguns fenômenos, dentre os quais destacamos: (1) presença do paradigma de ensino tradicional, marcado por práticas conteudistas e reprodutivas; (2) tempo insuficiente para o professor orientar toda uma turma a desenvolver atividades de pesquisa; e (3) necessidade de formaçăo profissional do professor para "educar pela pesquisa", nos termos utilizados por Demo (2011). E a respeito desse último fenômeno, salientamos a necessidade da reinvençăo dos currículos das licenciaturas, que, muitas vezes, fracassam na formaçáo inicial de professores incapazes de produzirem conhecimentos a partir da interlocuçâo com os alunos da escola básica e, até mesmo, com outros professores companheiros de jornada.

Finalmente, destacamos a relevância das feiras científicas escolares, a exemplo da FECIT e da FEBRACE, que criam demandas para o desenvolvimento de práticas pedagógicas informadas pela abordagem do letramento científico. É desejável que as atividades de iniciaçâo científica informem os conteúdos das disciplinas escolares e náo apareçam como conteúdos extras, encaixados num tempo delimitado, em fendas instauradas no cotidiano das aulas ministradas. A educaçâo científica também nâo pode sofrer o mal da pedagogizaçâo. 


\section{REFERÊNCIAS}

ANTUNES, Irandé. Textualidade: noçōes básicas e implicaçōes pedagógicas. Săo Paulo: Parábola, 2017.

ASSOCIAÇĀO BRASILEIRA DE NORMAS TÉCNICAS. ABNT. NBR 10520 - Informaçăo e documentaçăo - Citaçóes em documentos - apresentaçăo. Rio de Janeiro; 2002.

ASSOCIAÇĀO BRASILEIRA DE NORMAS TÉCNICAS. ABNT. NBR 15437-Informaçâo e documentaçăo - Pôsteres técnicos e científicos - apresentaçăo. Rio de Janeiro; 2006.

ASSOCIAÇĀO BRASILEIRA DE NORMAS TÉCNICAS. ABNT. NBR 6023 - Informaçăo e documentaçăo - Referências - apresentaçăo. Rio de Janeiro; 2002.

ASSOCIAÇÂO BRASILEIRA DE NORMAS TÉCNICAS. ABNT. NBR 6028 - Informaçăo e documentaçăo - Resumo - apresentaçăo. Rio de Janeiro; 2003.

BAKHTIN, Mikhail. Marxismo e filosofia da linguagem. Traduçăo Michel Lahud e Yara Frateschi Vieira. 6. ed. Săo Paulo: Hucitec, 1992.

BAKHTIN, Mikhail. Os gêneros do discurso. In: M. BAKHTIN. Estética da criaçâo verbal. Săo Paulo: Martins Fontes, 2003. pp. 261-306.

BAZERMAN, Charles. Gêneros textuais, tipificaçāo e interaçāo. In: A. P. DIONÍSIO; J. C. HOFFNAGEL (Orgs.). 4. ed. Săo Paulo: Cortez; 2011.

BERTOLDO, Raquel Roberta; CUNHA, Marcia. Borinda. Feiras de ciências na escola. Atos de pesquisa em educaçâo. Blumenau: FURB, v. 11, n. 1, p. 293-318, 2016.

CHASSOT, Attico. Alfabetizaçâo científica: questōes e desafios para a educaçâo. Ijuí: Editora Unijuí; 2003.

DEMO, Pedro. Educaçâo e alfabetizaçâo científica. Campinas: Papirus; 2011.

DE PABLOS, José Manuel de. Siempre ha habido infografia. In: Revista Latina de Comunicación Social. Número 5. Mayo de 1998. La Laguna. Tenerife. Disponível em: 〈http://www.ull.es/publicaciones/latina/a/88depablos.htm〉. Acesso em: 07 abr. 2016.

DELL'ISOLA, Regina Lúcia. Retextualizaçâo de gêneros escritos. Rio de Janeiro: Lucerna; 2007. FAIRCLOUGH, Norman. Discurso e mudança social. Coord. Trad. e prefácio Isabel Magalhăes. Brasília: UNB; 2001.

GEE, James Paul.; HAYES, Elisabeth. Language and learning in the digital age. London: Routledge; 2011.

HARGREAVES, Andy.; FINK, Dean. Liderança sustentável: desenvolvendo gestores da aprendizagem. Porto Alegre: Artmed; 2007.

IBGE. Normas de apresentaçăo tabular. 3. ed. Rio de Janeiro; 1993.

MACHADO, Irene. Argumentaçâo gráfica na prosa ensaística da revista Pesquisa FAPESP. Bakhtiniana. Săo Paulo, 11 (2): 111-136, Maio/Ago 2016.

MARCUSCHI, Luíz Antônio. Da fala para a escrita: atividade de retextualizaçâo. Sáo Paulo: Cortez; 2001. 
PALMAS. Diário Oficial da Uniăo (2014) - PORTARIA/GAB/SEMED/N0361. Disponível em:<http://www.jusbrasil.com.br/diarios/84404110/dom-pmw-normal-31-03-2014pg-12>. Acessado em: 18 mar 2015.

PALMAS. Secretaria Municipal de Educaçâo. Edital SEMED No 002/2014 - Feira de ciências, inovaçāo e tecnologia de Palmas - FECIT 2014 de Palmas. Disponível em: < http://ulbra-to.br/fecit/wp-content/uploads/2014/09/Edital-FECIT-2014.pdf>. 2014a. Acesso em: 30 set. 2015.

RIBEIRO, Ana Elisa. Letramento digital: um tema em gêneros efêmeros. Revista da ABRALIN. Curitiba: UFPR, v. 8, n. 1, p. 15-38, 2009.

SANTOS, Wildson Luiz. Educaçăo científica na perspectiva de letramento como prática social: funçôes, princípios e desafios. Revista Brasileira de Educaçâo, Rio de Janeiro, v. 12, n. 36, dez. 2007.

SASSERON, Lúcia Helena; CARVALHO, Anna Maria. Almejando a alfabetizaçăo científica no Ensino Fundamental: a proposiçăo e a procura de indicadores do processo. Investigaçóes em Ensino de Ciências, Porto alegre, v. 13, n. 3, p. 333-352, 2008.

SILVEIRA, Raimunda Araújo. Abordagem interdisciplinar de práticas sustentáveis de multiletramentos na escola tocantinense de tempo integral. Dissertaçăo em andamento (Mestrado Profissional em Letras - ProfLetras) - Universidade Federal do Tocantins, Araguaína, 2016.

SOARES, Magda. Letramento: um tema em três gêneros. Belo Horizonte: Autêntica Editora, 2001.

Recebido em novembro de 2017.

Aceite em fevereiro de 2018. 